\title{
Recombinant amyloid beta-peptide production by coexpression with an affibody ligand
}

\author{
Bertil Macao $^{\dagger 1}$, Wolfgang Hoyer ${ }^{\dagger 1}$, Anders Sandberg1, Ann- \\ Christin Brorsson², Christopher M Dobson ${ }^{2}$ and Torleif Härd*1,3
}

\author{
Address: ${ }^{1}$ Department of Medical Biochemistry, University of Gothenburg, PO Box 440, SE-405 30 Göeborg, Sweden, ${ }^{2}$ Department of Chemistry, \\ University of Cambridge, Lensfield Road, Cambridge CB2 1EW, UK and ${ }^{3}$ The Swedish NMR Centre, University of Gothenburg, Box 465 , SE-405 \\ 30 Göeborg, Sweden \\ Email: Bertil Macao - bertil.macao@medkem.gu.se; Wolfgang Hoyer - wolfgang.hoyer@medkem.gu.se; \\ Anders Sandberg - anders.sandberg@medkem.gu.se; Ann-Christin Brorsson - ahb28@cam.ac.uk; Christopher M Dobson - cmd44@cam.ac.uk; \\ Torleif Härd* - torleif.hard@gu.se \\ * Corresponding author †Equal contributors
}

Published: 30 October 2008

BMC Biotechnology 2008, 8:82 doi:10.1 |86/1472-6750-8-82
Received: 22 May 2008

Accepted: 30 October 2008

This article is available from: http://www.biomedcentral.com/1472-6750/8/82

(C) 2008 Macao et al; licensee BioMed Central Ltd.

This is an Open Access article distributed under the terms of the Creative Commons Attribution License (http://creativecommons.org/licenses/by/2.0), which permits unrestricted use, distribution, and reproduction in any medium, provided the original work is properly cited.

\begin{abstract}
Background: Oligomeric and fibrillar aggregates of the amyloid $\beta$-peptide (A $\beta$ ) have been implicated in the pathogenesis of Alzheimer's disease (AD). The characterization of $A \beta$ assemblies is essential for the elucidation of the mechanisms of $A \beta$ neurotoxicity, but requires large quantities of pure peptide. Here we describe a novel approach to the recombinant production of $A \beta$. The method is based on the coexpression of the affibody protein $Z_{A \beta 3}$, a selected affinity ligand derived from the $Z$ domain three-helix bundle scaffold. $Z_{A \beta 3}$ binds to the amyloidogenic central and $C$ terminal part of $A \beta$ with nanomolar affinity and consequently inhibits aggregation.
\end{abstract}

Results: Coexpression of $Z_{A \beta 3}$ affords the overexpression of both major $A \beta$ isoforms, $A \beta(I-40)$ and $A \beta(I-42)$, yielding 4 or $3 \mathrm{mg}$, respectively, of pure ${ }^{15} \mathrm{~N}$-labeled peptide per liter of culture. The method does not rely on a protein-fusion or -tag and thus does not require a cleavage reaction. The purified peptides were characterized by NMR, circular dichroism, SDS-PAGE and size exclusion chromatography, and their aggregation propensities were assessed by thioflavin $T$ fluorescence and electron microscopy. The data coincide with those reported previously for monomeric, largely unstructured $A \beta . Z_{A \beta 3}$ coexpression moreover permits the recombinant production of $A \beta(I-42)$ carrying the Arctic (E22G) mutation, which causes early onset familial $A D$. $A \beta(I-42) E 22 G$ is obtained in predominantly monomeric form and suitable, e.g., for NMR studies.

Conclusion: The coexpression of an engineered aggregation-inhibiting binding protein offers a novel route to the recombinant production of amyloidogenic $A \beta$ peptides that can be advantageously employed to study the molecular basis of $A D$. The presented expression system is the first for which expression and purification of the aggregation-prone Arctic variant (E22G) of $A \beta(I-42)$ is reported. 


\section{Background}

Alzheimer's disease (AD) is the most common neurodegenerative disorder, currently afflicting about 20 million people worldwide, with increasing prevalence in an ageing society [1]. AD is characterized by large extracellular deposits of senile plaques in the brain, consisting of aggregated, fibrillar amyloid $\beta$-peptide $(A \beta)$ [2,3]. Extensive evidence supports a critical role of soluble intermediary $\mathrm{A} \beta$ oligomers in the induction of synapse dysfunction and neurodegeneration [3-6]. A $\beta$ originates from proteolytic processing of the amyloid precursor protein (APP) [7]. APP is cleaved by the membrane associated $\beta$ - and $\gamma$-secretases that generate a number of differently sized peptides, of which $A \beta(1-40)$ and $A \beta(1-42)$ are most abundant. $\mathrm{A} \beta(1-42)$ is considerably more neurotoxic than $A \beta(1-$ $40)$, in agreement with its increased hydrophobicity and tendency to aggregate. Mutations within A $\beta$ are associated with familial AD and cerebral amyloid angiopathy. One example is the Arctic (E22G) mutation, which entails enhanced $A \beta$ protofibril formation and fibrillation and causes typical AD neuropathology $[8,9]$.

Despite the fact that much effort has been put into $A \beta$ related research, many questions still need to be answered. Most importantly, the precise mechanisms of A $\beta$ toxicity remain to be understood [3]. In this context, an inventory of oligomeric and protofibrillar $A \beta$ species would be desirable, detailing their biophysical properties and contributions to neurodegeneration. The extension and refinement of existing structural data on $A \beta$ oligomers and fibrils [10-12] would help to derive structure-toxicity relationships and thus support AD drug discovery efforts. The accessibility of large amounts of $A \beta$ peptide is a prerequisite for these studies.

The majority of research using $A \beta$ peptides within the areas of biochemistry, biophysics and cell biology is conducted with synthetic peptides. An alternative to chemical synthesis is recombinant expression in Escherichia coli, which is advantageous because of its low cost, the fast growth to high expression levels and the availability of established cloning and expression protocols [13]. Recombinant expression is particularly attractive for structural biology projects, as it enables the production of milligram quantities of isotope or seleno-methionine labeled peptide for structure determination by nuclear magnetic resonance (NMR) spectroscopy or x-ray crystallography at reasonable cost.

Prokaryotic expression and purification of highly amyloidogenic peptides such as $\mathrm{A} \beta$ has proven difficult due to their small size, their tendency to aggregate and the toxicity of the formed aggregates [14]. Protein fusions, which might protect from proteolysis and enhance solubility, are typically used to tackle these problems $[13,15,16]$. The expression of $A \beta(1-40)$ or $A \beta(1-42)$ fused to segments of a surface protein from the malaria parasite Plasmodium falciparum [17], maltose binding protein [18], ubiquitin [19], GroES-ubiquitin [20], trigger factor-ubiquitin [21], and hen egg white lysozyme [22] has been reported. In order to obtain $A \beta$ unaffected by the tag, its removal by site specific proteolysis is an inevitable additional purification step in all of these cases. The proteolytic cleavage reaction is cost-intensive, requires time-consuming optimization and necessitates post-reaction clean-up, which further reduces the attainable yield.

An alternative method to increase the yield of troublesome target proteins is coexpression with proteins that stabilize the target, assist with its folding, or prevent its aggregation [23]. This technique has permitted heterologous expression of macromolecular complexes, whose components could not be obtained individually [24-27]. Co-overexpression of molecular chaperones can increase the yield of targets to varying extents [28,29].

Here we present a novel approach to the recombinant production of amyloidogenic $A \beta$ peptides. $A \beta$ is obtained by coexpression with an engineered binding protein that specifically binds and stabilizes the monomeric peptide. The binding protein, termed $\mathrm{Z}_{\mathrm{A} \beta 3}$, belongs to the class of affibody affinity ligands [30,31]. Affibody proteins have found applications in biotechnology, biochemical assays, disease diagnosis and therapy [31]. They are selected by phage display from libraries based on the 58 amino acid three-helix bundle scaffold of the $\mathrm{Z}$ domain derived from staphylococcal protein $A$ [32]. $Z_{A \beta 3}$ is a disulfide-linked homodimer of affibody subunits that binds monomeric $\mathrm{A} \beta$ with nanomolar affinity [33] (Figure 1). In contrast to the majority of $\mathrm{A} \beta$-antibodies [34], $\mathrm{Z}_{\mathrm{A} \beta 3}$ targets the highly amyloidogenic central and C-terminal part of $A \beta$ (residues 17-36). This region adopts a $\beta$-hairpin conformation upon binding and is buried within a hydrophobic tunnellike cavity formed by $Z_{A \beta 3}$. Consequently, $A \beta$ oligomerization and fibrillation are inhibited by stoichiometric concentrations of $\mathrm{Z}_{\mathrm{A} \beta 3}$ [33].

The concept of producing $A \beta$ by recombinant coexpression with $Z_{\mathrm{A} \beta 3}$ offers several potential advantages: (i) Binding of the coexpressed $Z_{A \beta 3}$ to the amyloidogenic sequence region of $A \beta$ could retain the peptide in a monomeric state during expression and the initial purification steps, thereby preventing any cell toxicity exerted by aggregates and facilitating purification. (ii) $\mathrm{A} \beta$ is largely unfolded in its unbound monomeric state [35], and the complex might therefore protect the peptide from degradation. (iii) Both coexpression of auxiliary proteins and protein fusions impose additional metabolic burden on host cells, but the small size of the affibody scaffold limits 


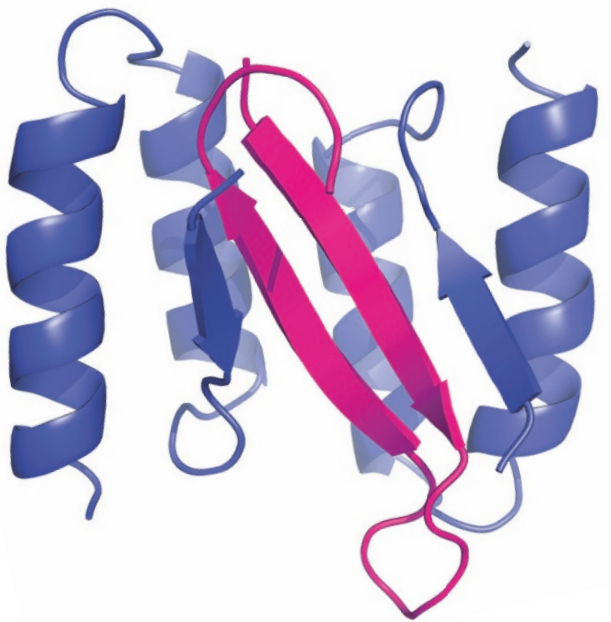

\section{Figure I}

Structure of the $A \beta(1-40): Z_{A \beta 3}$ complex. Ribbon drawing of the topology of the complex [33]. $A \beta(I-40)$ is shown in magenta, $\mathrm{Z}_{\mathrm{A} \beta 3}$ in blue. The disordered $\mathrm{N}$-termini are not displayed. The image was generated using PyMOL (DeLano Scientific).

this burden, which is especially important when short peptides such as $A \beta$ are to be expressed.

In the present implementation of the $A \beta: Z_{A \beta 3}$ coexpression system, $A \beta$ is expressed tag-less, offering a particularly facile route to obtain pure peptide. As a consequence, a methionine resulting from the obligatory translation start codon is obtained $\mathrm{N}$-terminal of $\mathrm{A} \beta$. The resulting peptide will thus be referred to as MA $\beta$ below.

We report the expression and purification of ${ }^{15} \mathrm{~N}$-labeled $M A \beta(1-40), M A \beta(1-42)$ and $M A \beta(1-42) E 22 G$ by $Z_{A \beta 3}$ coexpression. The method yields pure, fibrillation-competent, monomeric peptides with conformational properties and aggregation propensities indistinguishable from those of the respective $A \beta$ peptides.

\section{Results}

\section{Expression and purification of MA $\beta$ peptides}

A double cistronic coexpression vector based on the bacterial expression vector pACYCDuet-1 (Novagen) was constructed. The coexpression vector contains the genes for $M A \beta[M A \beta(1-40), M A \beta(1-42)$, or $M A \beta(1-42) E 22 G]$ and (His) ${ }_{6}$-tagged $Z_{A \beta 3}$ in the following order: T7 promoter-1 - MA $\beta$ - T7promoter-2 - (His) ${ }_{6} Z_{A \beta 3}-$ T7 terminator. MA $\beta$ is effectively overexpressed and obtained in the soluble fraction of cell lysates, indicating that its complex with the disulfide-linked $Z_{\mathrm{A} \beta 3}$ dimer is formed and stable in the E. coli cytosol (Figure 2, lane 2).

In the present system, the auxiliary protein $\mathrm{Z}_{\mathrm{A} 33}$ is (His) ${ }_{6}{ }^{-}$ tagged but not the target peptide, permitting the purification of tag-free MA $\beta$ without a cleavage reaction. MA $\beta$ is captured in complex with $Z_{\mathrm{A} \beta 3}$ by immobilized metal ion affinity chromatography (IMAC) (Figure 2, lane 4), demonstrating that the $M A \beta: Z_{A \beta 3}$ complex remains stable during the initial purification steps. Resonances in the ${ }^{15} \mathrm{~N}$ heteronuclear single quantum correlation (HSQC) NMR spectrum of the coexpressed $M A \beta(1-40): Z_{A \beta 3}$ complex coincide with those of the native $A \beta(1-40): Z_{A \beta 3}$ complex, indicating that their structures are identical (Figure 3 ). $M A \beta$ is not detected in the IMAC wash fraction (Fig. 2, lane 3). Dissociation of the complex during IMAC is consequently not limiting the peptide yield.

Separation of the MA $\beta: Z_{A \beta 3}$ complex is achieved by IMAC under denaturing conditions. Pure monomeric MA $\beta$ is subsequently obtained by application of the denatured peptide to size exclusion chromatography (SEC) using native running buffer, e.g., $20 \mathrm{mM}$ sodium phosphate, 50 mM sodium chloride, $\mathrm{pH}$ 7.2.

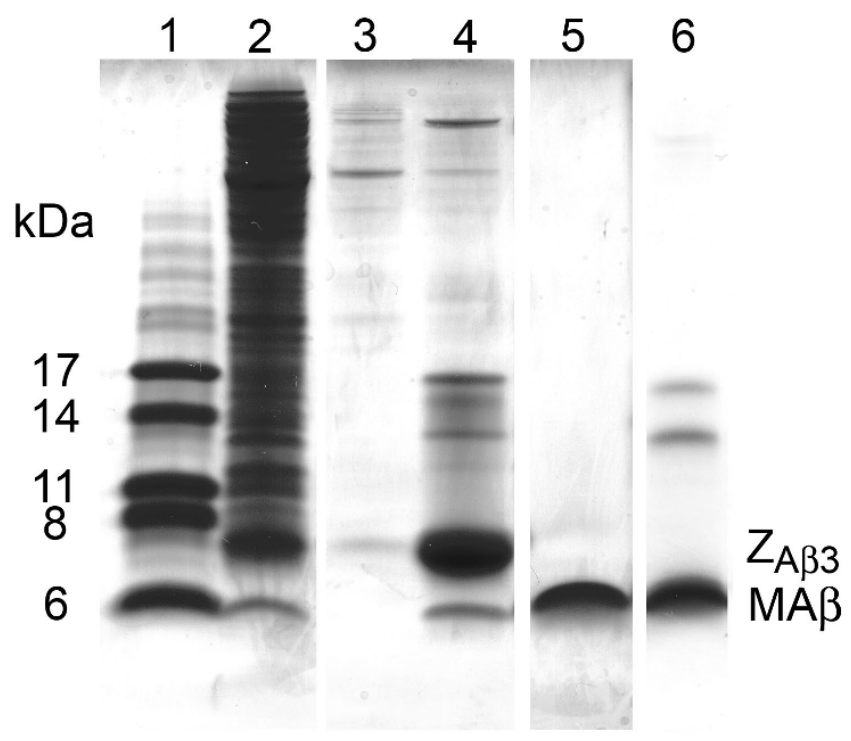

Figure 2

Purification of MA $\beta$ peptides. SDS-PAGE on a $16.5 \%$ Tris-Tricine gel at $4^{\circ} \mathrm{C}$. Lane I: Marker. 2: Cell lysate after $\mathrm{MA} \beta(\mathrm{I}-40)$ coexpression. 3: IMAC wash fraction ( $10 \mathrm{mM}$ imidazole). 4: IMAC eluate after addition of $150 \mathrm{mM}$ imidazole, demonstrating the effective capture of the $Z_{A \beta 3}: M A \beta(I-$ 40) complex. 5: Purified MA $\beta(I-40)$. 6: Purified MA $\beta(I-42)$. Samples were incubated for $2 \mathrm{~min}$ at $95^{\circ} \mathrm{C}$ prior to loading. 


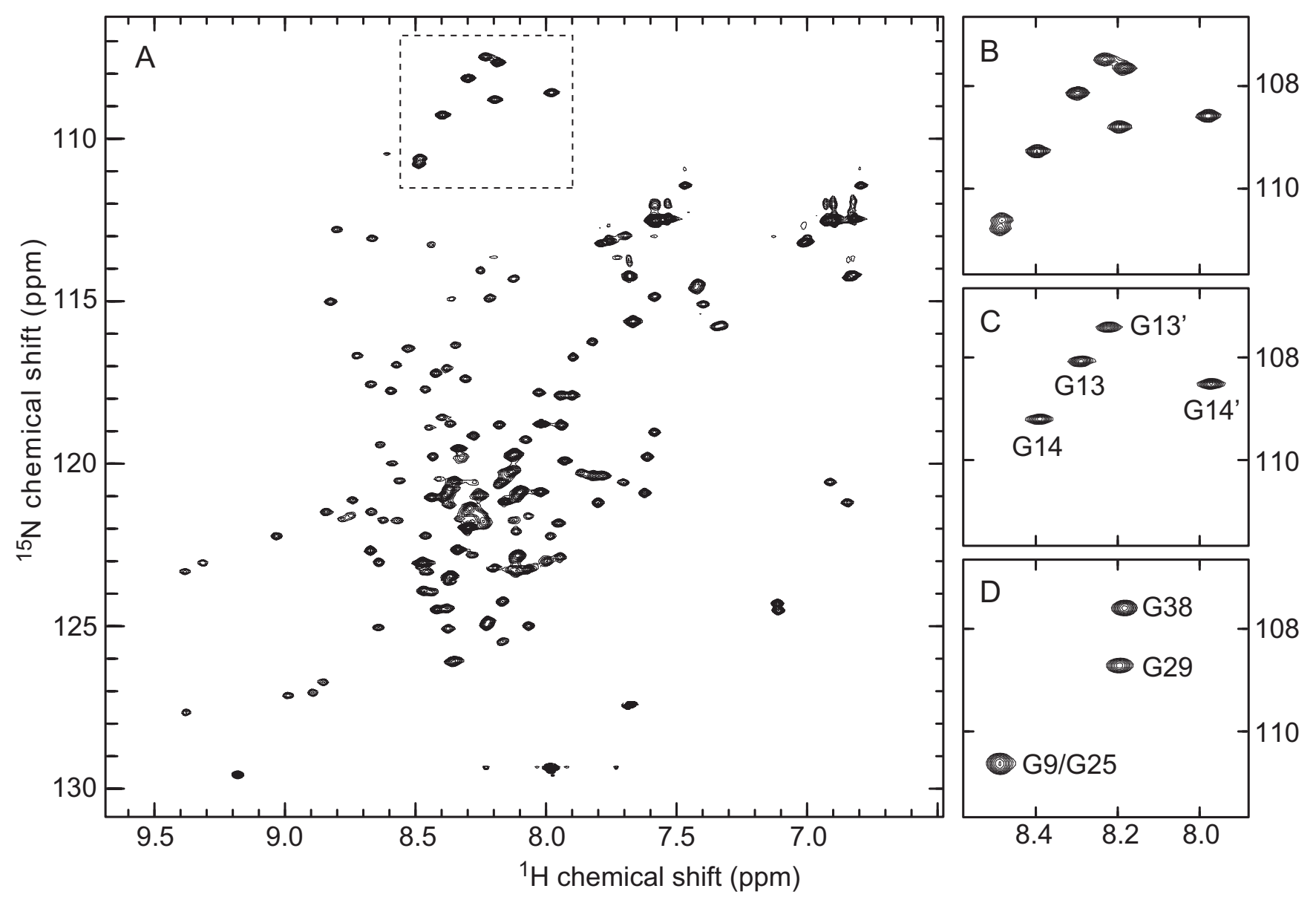

Figure 3

NMR spectroscopy of purified $M A \beta: Z_{A \beta 3}$ complex. (A) ${ }^{15} \mathrm{~N}$ HSQC NMR spectrum of the ${ }^{15} \mathrm{~N}$-labeled $M A \beta(I-40): Z_{A \beta 3}$ complex. The complex was obtained from coexpression and purified by IMAC (elution of the intact complex with I50 mM imidazole) and SEC. (B)-(D) Comparison of the glycine region (B; boxed area in panel $A$ ) with corresponding regions of ${ }^{15} \mathrm{~N}$ HSQC spectra of $A \beta(I-40): Z_{A \beta 3}$ samples in which either $Z_{A \beta 3}(C)$ or $A \beta(I-40)(D)$ are $15 N$-labeled. Sequential assignments of glycine resonances for the two $Z_{A \beta 3}$ subunits and bound $A \beta(1-40)$ are given in panels $C$ and $D$, respectively. The occurrence of resonances at identical chemical shifts in complexes of $Z_{A \beta 3}$ with recombinant $M A \beta(I-40)$ and native $A \beta(I-40)$ peptides indicates that the structures of the two complexes are the same. NMR was measured at $25^{\circ} \mathrm{C}$ at $800 \mathrm{MHz}(\mathrm{A}, \mathrm{B}$ and $\mathrm{D})$ or 900 $\mathrm{MHz}(\mathrm{C})$ on samples containing $160 \mu \mathrm{M}(\mathrm{A}, \mathrm{B}), 450 \mu \mathrm{M}(\mathrm{C})$ or $400 \mu \mathrm{M}$ (D) complex in 20 mM potassium (A, B) or sodium (C, D) phosphate, with $0.1 \%$ azide and $10 \% \mathrm{D}_{2} \mathrm{O}$ at $\mathrm{pH} 7.2$.

SDS-PAGE shows a single band corresponding to the monomeric peptide in the case of purified $M A \beta(1-40)$, whereas two additional bands at higher molecular weight, approximately at 12 and $15 \mathrm{kDa}$, are observed for MA $\beta(1-$ 42) (Figure 2). These bands have been observed before and have been attributed to the SDS-induced formation of $\mathrm{A} \beta(1-42)$ oligomers [4,36]. Mass spectrometry confirmed that the bands consist of $\mathrm{MA} \beta(1-42)$.

The peptide yield from a $1 \mathrm{~L}$ culture was $4 \mathrm{mg}$ of $\mathrm{MA} \beta(1-$ $40)$ or $3 \mathrm{mg}$ of $M A \beta(1-42)$. Purification of $Z_{A \beta 3}$ from an $\mathrm{MA} \beta(1-40)$ coexpression culture gave $23 \mathrm{mg}$ of the dimeric protein per $1 \mathrm{~L}$ of culture, indicating that $~ 60 \%$ of the expressed $Z_{A \beta 3}$ was in complex with $M A \beta(1-40)$, whereas the rest remained unbound.

\section{Comparison of $\mathrm{MA} \beta$ with $\mathrm{A} \beta$}

Several different techniques were used to establish that $\mathrm{MA} \beta$ and $\mathrm{A} \beta$ possess identical conformational properties and aggregation propensities. $M A \beta$ and $A \beta$ are indistinguishable by SDS-PAGE (Figure 4A). The extent of SDSinduced oligomer formation of $\mathrm{MA} \beta(1-42)$ is the same as for $A \beta(1-42)$ and increases with temperature.

In SEC, which separates molecules based on their hydrodynamic volume, very similar elution volumes are 
A

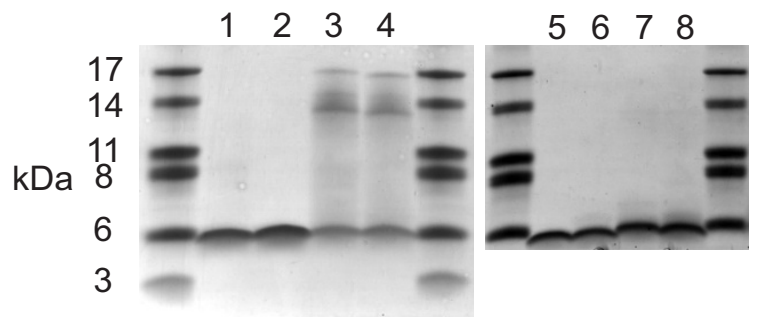

B

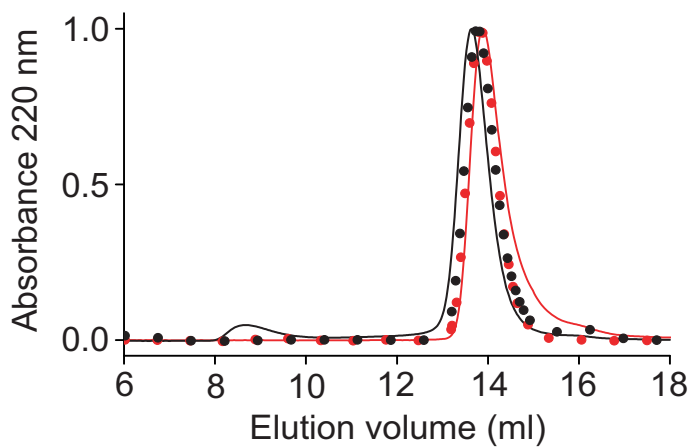

C

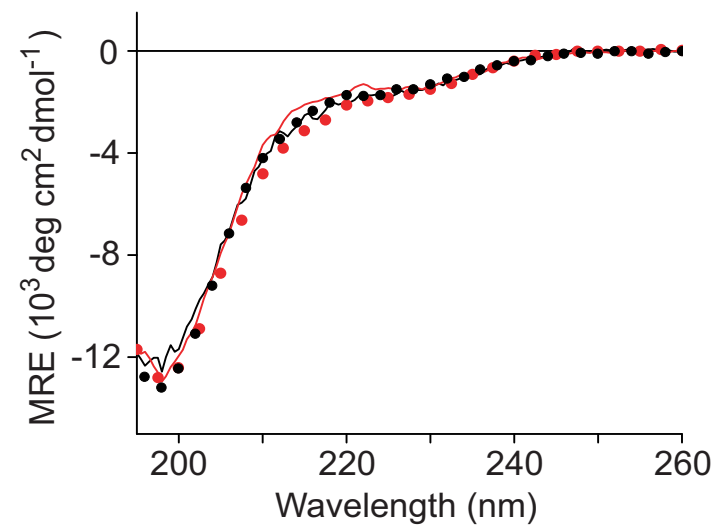

D

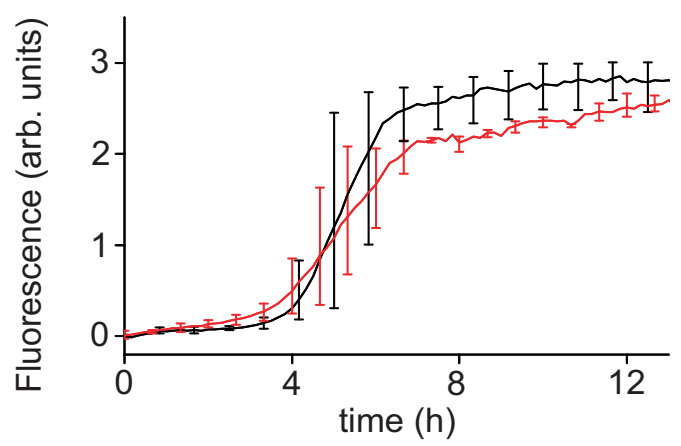

E

$\mathrm{F}$
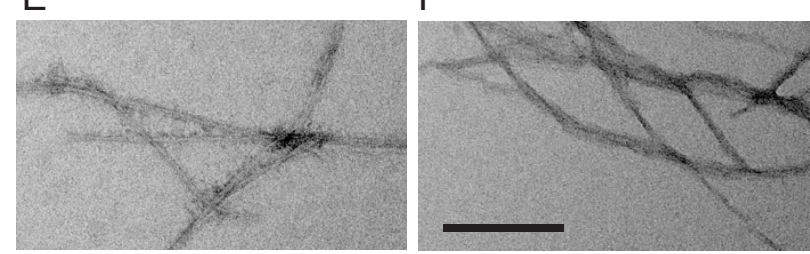

Figure 4

\section{Figure 4}

Comparison of MA $\beta$ with A $\beta$. (A) SDS-PAGE using $16.5 \%$

Tris-Tricine gels at $21^{\circ} \mathrm{C}$ (lanes I-4) or $4^{\circ} \mathrm{C}$ (lanes 5-8). Lanes I and 5: $M A \beta(I-40) .2$ and 6: $A \beta(I-40) .3$ and 7: $M A \beta(I-42) .4$ and $8: A \beta(I-42)$. Unlabeled lanes contain marker. Samples were incubated for 2 min at $95^{\circ} \mathrm{C}$ prior to loading. (B) Elution profiles of analytical SEC of $M A \beta(I-40)$ (red line), $A \beta(I-40)$ (red circles), $M A \beta(I-42)$ (black line), $A \beta(I-42)$ (black circles). (C) Far-UV CD spectra of MA $\beta(I-$ 40) (red line), $A \beta(I-40)$ (red circles), $M A \beta(I-42)$ (black line), $A \beta(I-42)$ (black circles). (D) Kinetics of amyloid fibril formation of $M A \beta(I-42)$ (red) and $A \beta(I-42)$ (black) monitored by thioflavin T fluorescence. The average of 3 time traces is shown with error bars representing the maximal and minimal values. The peptides were used at $25 \mu \mathrm{M}$ in $20 \mathrm{mM}$ sodium phosphate, $50 \mathrm{mM}$ sodium chloride, $10 \mu \mathrm{M}$ thioflavin $\mathrm{T}, \mathrm{pH}$ 7.2. Temperature, $37^{\circ} \mathrm{C}$. $(\mathrm{E})$ and $(\mathrm{F})$ Electron micrographs of amyloid fibrils formed by $M A \beta(I-42)(E)$ and $A \beta(I-42)(F)$. Scale bar, $200 \mathrm{~nm}$.

obtained for $M A \beta$ and $A \beta$ (Figure 4B). The elution volumes correspond to a molecular weight of $\sim 11 \mathrm{kDa}$ on a scale calibrated with globular protein standards, in agreement with previous SEC studies [37]. The high apparent molecular weight (the nominal weights of the $A \beta$ and MA $\beta$ peptides are in the range of 4.3 to $4.7 \mathrm{kDa}$ ) is expected for a peptide that is disordered and consequently has a larger hydrodynamic volume than a globular protein of the same molecular weight.

The secondary structure content was analyzed by circular dichroism (CD) spectroscopy (Figure 4C). Far-UV CD spectra of MA $\beta$ conformed to those of $A \beta$, featuring a minimum at $\sim 198 \mathrm{~nm}$ that is characteristic of the predominantly random coil conformation detected in nonaggregated $A \beta$ peptides $[38,39]$.

The ${ }^{15} \mathrm{~N}$ HSQC NMR spectra of MA $\beta(1-40)$ and MA $\beta(1-$ $42)$ strongly resemble those of $A \beta(1-40)$ and $A \beta(1-42)$, respectively (Figure 5). The large majority of $A \beta$ backbone amide resonances are recovered at identical positions in the MA $\beta$ spectra. Differences in chemical shifts are only observed for residues N-terminal of Arg5. Such local shift changes are a mandatory consequence of the modification of the peptide sequence, in this case with the N-terminal methionine, and reflect local changes in the electronic environment. However, the chemical shift differences do not demonstrate any change in peptide conformation. The ${ }^{15} \mathrm{~N}$ HSQC spectra prove that Met35 is unoxidized, by comparison with reference spectra for $A \beta(1-40)$ and $\mathrm{A} \beta(1-42)[35]$, in agreement with the mass spectrometry results. 

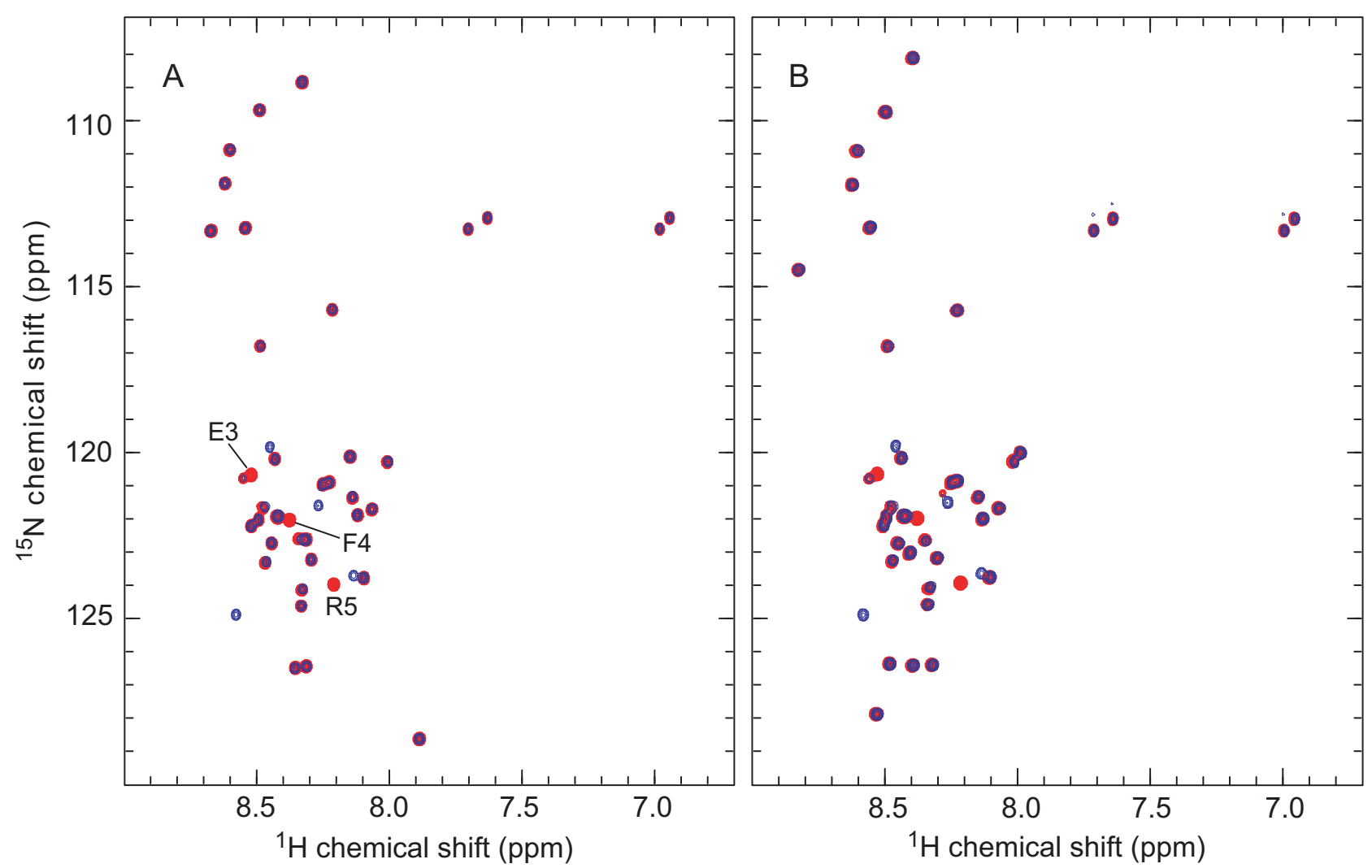

Figure 5

NMR spectroscopy of MA $\beta .{ }^{15} \mathrm{~N} H S Q C N M R$ spectra of $M A \beta(I-40)(A$, blue), $A \beta(I-40)(A$, red), $M A \beta(I-42)(B, b l u e)$ and $A \beta(I-42)\left(B\right.$, red) at $5^{\circ} \mathrm{C}$ at $800 \mathrm{MHz}$. The spectra illustrate the purity of the recombinantly expressed peptides. The chemical shifts and sharp NMR resonances indicate that the peptides exist in disordered monomeric conformations. Resonances of $A \beta(I-40)$ that are displaced as a consequence of the presence of the $N$-terminal methionine in $M A \beta(I-40)$ are indicated. Assignments were obtained from literature spectra [35,52].

The enhanced fluorescence emission of the dye thioflavin $\mathrm{T}$ upon binding to amyloid fibrils is frequently used to monitor fibrillation [40]. The fibrillation kinetics of $A \beta(1-42)$ and $M A \beta(1-42)$ are identical within the error of the experiment (Figure 4D). The presence of amyloid fibrils in the final steady-state of fibrillation was confirmed by electron microscopy (Figure 4E and 4F).

\section{Production and characterization of MA $\beta(I-42) E 22 G$}

The Arctic mutant of $A \beta$ is a particularly interesting variant inasmuch as it links an increased tendency for protofibril formation and fibrillation to early onset familial AD [8,9]. To our knowledge, no protocol for the recombinant production of $A \beta(1-42) E 22 G$ has been reported to date, possibly due to the extreme aggregation propensity of this peptide variant. Coexpression of $\mathrm{Z}_{\mathrm{A} \beta 3}$ permitted the production of MA $\beta(1-42) E 22 \mathrm{G}$ with a yield of $1 \mathrm{mg}$ from a 1 L culture. SDS-PAGE demonstrates increased oligomerization of $M A \beta(1-42) E 22 G$ compared to $M A \beta(1-42)$ (Figure $6 A)$. The major fraction of purified MA $\beta(1-42) E 22 G$ is present in monomeric form as evidenced by SEC, which gives an elution volume of $\sim 14 \mathrm{~mL}$ (Figure $6 \mathrm{~B}$ ), similar to that of monomeric $M A \beta(1-40)$ and $M A \beta(1-42)$ (Figure $4 \mathrm{~B})$. Recombinant $\mathrm{MA} \beta(1-42) \mathrm{E} 22 \mathrm{G}$ can be employed, e.g., for NMR spectroscopy. The ${ }^{15} \mathrm{~N}$ HSQC NMR spectrum of $\mathrm{MA} \beta(1-42) \mathrm{E} 22 \mathrm{G}$ is displayed in Figure $6 \mathrm{C}$. As expected, the resonances of backbone amides in the vicinity of residue 22 are affected by the E22G mutation due to the removal of one negative charge. However, the changes are not large and the E22G mutant is also disordered in its monomeric state.

\section{Discussion}

We have shown that coexpression of the $\mathrm{Z}_{\mathrm{A} \beta 3}$ affibody protein enables recombinant production of MA $\beta$ peptides. $\mathrm{Z}_{\mathrm{A} \beta 3}$ binds to the amyloidogenic, hydrophobic central and $\mathrm{C}$-terminal region of $\mathrm{A} \beta$ and thus prevents peptide aggregation and potential detrimental effects on cellular homeostasis. $\mathrm{MA} \beta$ is released from $\mathrm{Z}_{\mathrm{A} \beta 3}$ only after an initial purification of the complex has been achieved, limiting the potential for adverse effects during peptide preparation. 
A
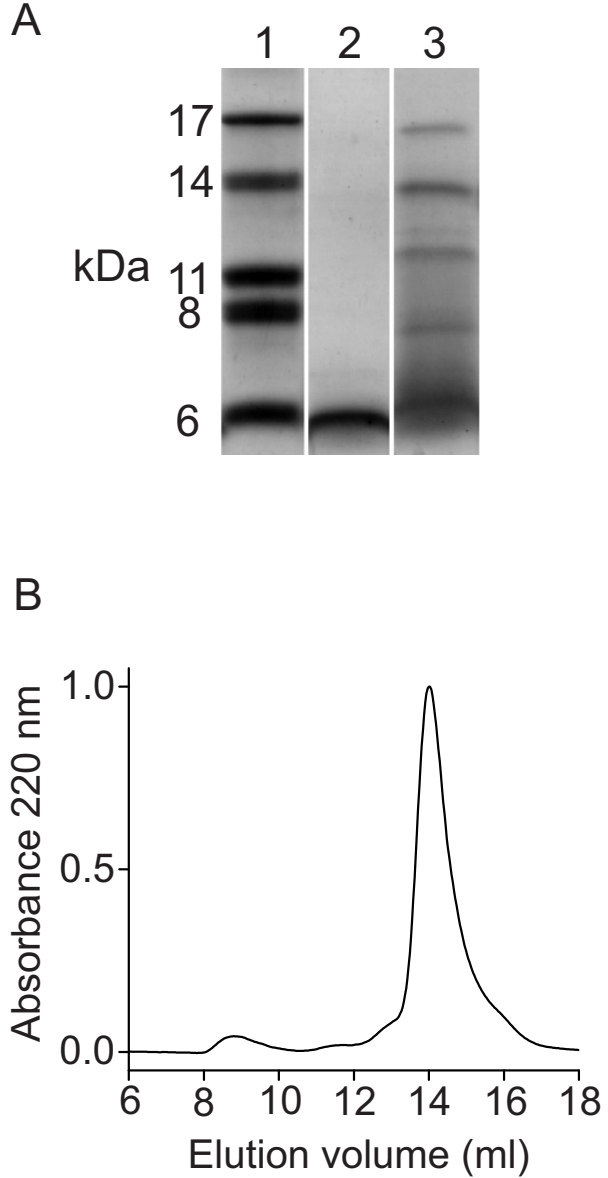

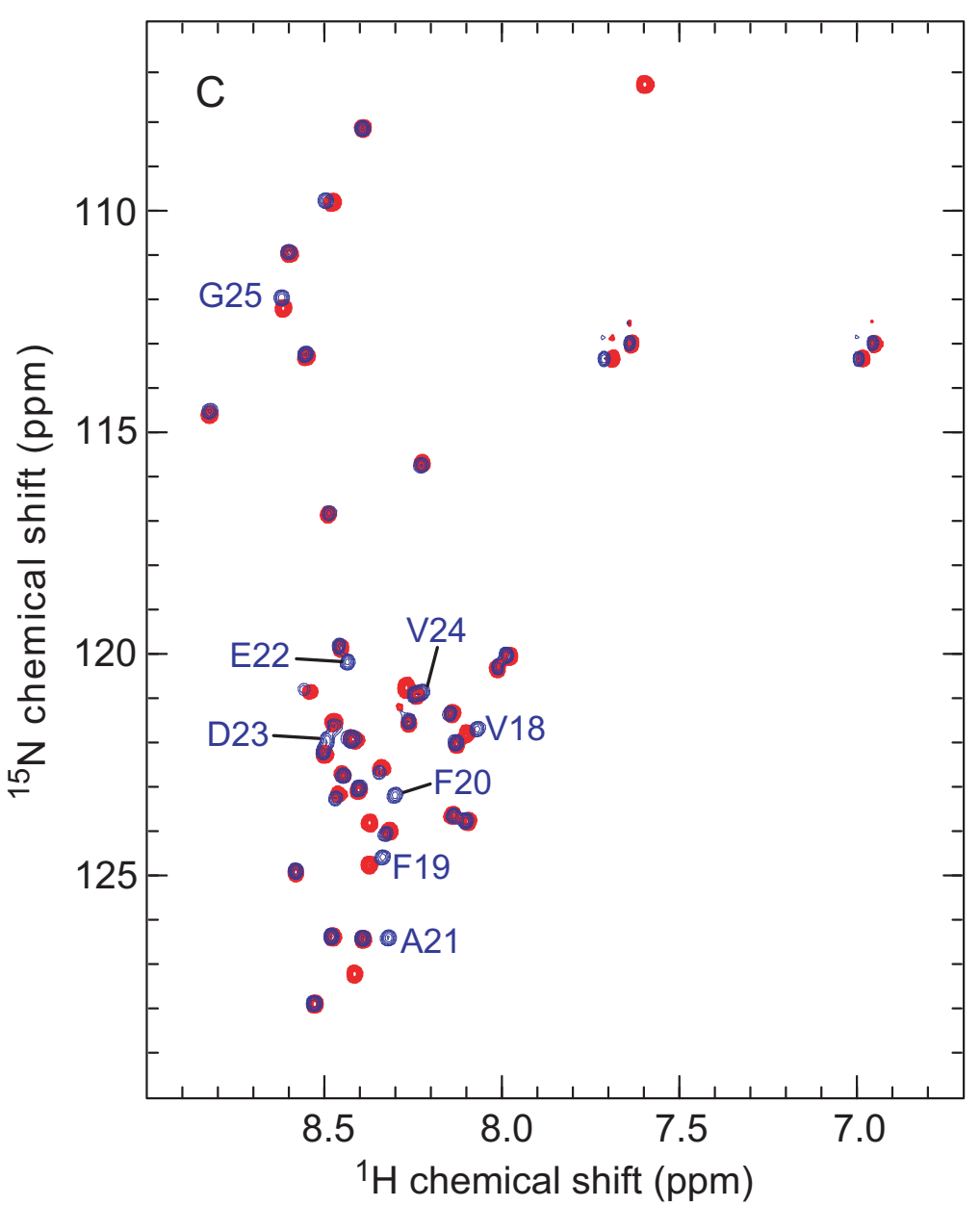

Figure 6

Recombinant expression of MA $\beta$ (I-42)E22G. (A) SDS-PAGE using a 16.5\% Tris-Tricine gel at $4^{\circ} \mathrm{C}$. Lane I: Marker. 2 : MA $\beta(I-42)$. 3: MA $\beta(I-42) E 22 G$. (B) Elution profile of analytical SEC of purified MA $\beta(I-42) E 22 G$. (C) ${ }^{15} \mathrm{~N}$ HSQC NMR spectra of $M A \beta(I-42)$ (blue) and MA $\beta(I-42) E 22 \mathrm{G}$ (red) at $5^{\circ} \mathrm{C}$ at $800 \mathrm{MHz}$. Resonances of $\mathrm{MA} \beta(\mathrm{I}-42)$ that are lost or displaced as a consequence of the E22G mutation are indicated. Assignments were obtained from literature spectra [35,52].

Coexpression is particularly profitable for the production of unstructured proteins that exhibit folding coupled to binding to the coexpressed partner [41]. The $A \beta: Z_{A \beta 3}$ interaction is characterized by extensive coupled folding and binding of both binding partners $[33,42]$. In addition to increasing the thermodynamic stability of the complex's constituents, coupled folding-binding presumably also reduces their susceptibility to proteolytic degradation.

Just as protein fusion tags preferably should be short, coexpression systems profit from a small size of the auxiliary protein, as this limits the metabolic burden. The affibody scaffold used for engineering $Z_{A \beta 3}$ is particularly small and a large fraction of the surface area is involved in the interaction with the target $[31,43]$. Affibody ligands therefore represent promising auxiliary proteins for the development of coexpression systems, as exemplified in this study.

In contrast to previously published methods for recombinant expression of $\mathrm{A} \beta[17-22,44]$, the present system does not require a cleavage reaction. The reported cleavage reactions are time-consuming and/or expose the peptide to elevated temperature (typically, $37^{\circ} \mathrm{C}$ ), which is detrimental to the production of aggregation-prone peptides [20]. All of these methods moreover include a reverse phase chromatography step, which necessitates thorough subsequent disaggregation of $\mathrm{A} \beta$ peptides $[38,45,46]$. The coexpression system avoids acidic $\mathrm{pH}$ and organic solvents, and non-aggregated MA $\beta$ in buffered aqueous solution is obtained directly from size exclusion chromatography. Some of the expression methods previ- 
ously reported have further specific disadvantages compared to the present system: The cleavage reaction causes microheterogeneities [17], Met35 is oxidized [17], the peptide yield is lower [22], or the peptide contains additional residues at the $\mathrm{N}$-terminus [44,47]. In the case of the maltose binding protein fusion, a far greater peptide yield has been achieved [18]. This can in part be explained by the use of a fermentation system, which allows higher cell densities to be reached, frequently resulting in $>10$ fold the amount of purified protein in comparison to shake flask cultures $[48,49]$. The maltose binding protein fusion has only been used for production of the less aggregation-prone variant $A \beta(1-40)$ and provides peptide that aggregates into predominantly non-fibrillar structures $[50,51]$.

The MA $\beta$ peptides contain a methionine $\mathrm{N}$-terminal of the $A \beta$ sequence, originating from the translation start codon. However, according to the biochemical and biophysical analysis of the peptides by SDS-PAGE, SEC, NMR and CD spectroscopy, and to their aggregation propensity and aggregate morphology, the MA $\beta$ peptides faithfully recapitulate the properties of $A \beta$. The present coexpression system could be adapted to provide the peptide free of the additional $\mathrm{N}$-terminal methionine by expressing a suitably tagged $A \beta$ peptide that can be cleaved to yield the native $\mathrm{N}$-terminus. This would however delimit the ease and cost-effectiveness of the method. Alternatively, secretion signal sequences could be added to both $A \beta$ and affibody. These would be expected to be proteolyzed upon secretion and $\mathrm{A} \beta$ would thereby obtain its native $\mathrm{N}$-terminus.

The ${ }^{15} \mathrm{~N}$ HSQC NMR spectra of MA $\beta$ and $A \beta$ presented here superimpose on those reported previously in studies that thoroughly characterized $A \beta$ as largely monomeric under the applied experimental conditions $[35,52]$. This is in agreement with the observation that purified $M A \beta$ and $A \beta$ adopt a predominantly random coil conformation (Figure 4C). We conclude that MA $\beta$ is purified in nonaggregated, monomeric form and applicable as starting material for the investigation of fibril (Figure 4D) and oligomer formation. The potential to obtain labeled peptide makes MA $\beta$ suitable for structural studies by, e.g., NMR spectroscopy. The coexpression system is compatible with the overexpression of the highly aggregation prone Arctic mutant of MA $\beta(1-42)$ and can therefore be utilized to analyze the structural consequences of this and presumably other disease-related mutations of full-length $A \beta(1-$ 42). Previous systematic NMR studies on clinically relevant amino acid substitutions have pointed to a connection between monomer folding and oligomerization propensity, but were limited to decapeptide segments of $\mathrm{A} \beta[53]$.

\section{Conclusion}

We have described a recombinant expression system that provides facile access to both major isoforms of the highly amyloidogenic $A \beta$ peptide by coexpression of an engineered aggregation-inhibiting binding protein. The method also allows for the production of the particularly oligomerization and fibrillation-prone Arctic (E22G) mutant of $A \beta(1-42)$. The peptides are obtained in nonaggregated, monomeric form and can be favorably applied for the investigation of $A \beta$ oligomerization and fibrillation, inclusive of structural biology studies.

\section{Methods \\ Cloning}

The bacterial expression vector pACYCDuet-1 (Novagen) is designed for the double cistronic coexpression of two target genes and contains two multiple cloning sites (MCS), each of which is preceded by a T7 promoter/lac operator and a ribosome binding site. pACYCDuet-1 encoding $A \beta(1-40)$ with an additional N-terminal methionine, cloned as a NcoI/HindIII fragment at MCS 1 , was obtained from GENEART. The expression plasmid pAY 442 encoding (His) ${ }_{6}$-tagged $Z_{A \beta 3}$ [30] was digested with NdeI and Bpu1102I (all enzymes supplied by New England Biolabs), followed by insertion of the (His) ${ }_{6}-Z_{A \beta 3}$ gene into MCS2 of pACYCDuet-1 at the respective restriction sites. The resulting coexpression vector contains the genes in the following order: T7 promoter- $1-\mathrm{MA} \beta(1-40)$ - T7promoter- 2 - (His ${ }_{6} \mathrm{Z}_{\mathrm{A} \beta 3}-\mathrm{T} 7$ terminator. The vectors for coexpression of MA $\beta(1-42)$ and $M A \beta(1-42) E 22 G$ were generated by site-directed mutagenesis (Stratagene QuikChange mutagenesis kit) of the $M A \beta(1-40)$ or MA $\beta(1-42)$ expression clones, respectively.

\section{Protein expression}

BL21(DE3) E. coli cells (Novagen) were transformed with the expression vectors and grown for $\sim 16 \mathrm{~h}$ at $37^{\circ} \mathrm{C}$ on $\mathrm{LB}$ agar plates containing $34 \mu \mathrm{g} / \mathrm{mL}$ chloramphenicol. Single colonies were picked and grown for $\sim 16 \mathrm{~h}$ in $20 \mathrm{~mL}{ }^{15} \mathrm{~N}$ labeled $\mathrm{M} 9$ medium, containing $1 \mathrm{~g} / \mathrm{L}{ }^{15} \mathrm{NH}_{4} \mathrm{Cl}, 2 \mathrm{~g} / \mathrm{L}$ glucose, $2 \mathrm{mM} \mathrm{MgSO}_{4}, 0.1 \mathrm{mM} \mathrm{CaCl}_{2}, 2 \mathrm{~g} / \mathrm{L}$ natural ${ }^{15} \mathrm{~N}$-Celtone powder (Spectra Stable Isotopes) and $34 \mu \mathrm{g} / \mathrm{mL}$ chloramphenicol. The pre-culture was transferred to $1 \mathrm{~L}$ of ${ }^{15} \mathrm{~N}$-labeled M9-Celtone medium in a $5 \mathrm{~L}$ baffled Erlenmeyer flask. The culture was grown at $37^{\circ} \mathrm{C}$ with shaking and induced at OD $600 \sim 0.8$ by the addition of IPTG to a final concentration of $1 \mathrm{mM}$. After further growth for 4 hours the cells were harvested and frozen at $-20^{\circ} \mathrm{C}$. If isotopic labeling was not required, TB medium was used as an alternative to M9-Celtone.

\section{Purification of MA $\beta$}

The cell pellet from $1 \mathrm{~L}$ of bacterial culture was thawed in an ice/water bath, resuspended in $15 \mathrm{~mL}$ of buffer $\mathrm{A}$ ( 50 $\mathrm{mM}$ sodium phosphate, $0.2 \mathrm{M}$ sodium chloride, $1 \mathrm{mM}$ 
PMSF, pH 7.2) and subjected to three freeze-thaw cycles, followed by sonication according to a standard protocol. The lyzed cells were clarified by centrifugation at $17,000 \mathrm{~g}$ in a JA 25.50 rotor (Beckman) at $4^{\circ} \mathrm{C}$ for $30 \mathrm{~min}$.

For capture of the $M A \beta: Z_{A \beta 3}$ complex by IMAC, the supernatant was added to $10 \mathrm{~mL}$ HIS-Select $\mathrm{Ni}^{2+}$ affinity gel (Sigma-Aldrich) equilibrated in buffer A, and the mixture was incubated batch wise on a roller shaker for $20 \mathrm{~min}$ at room temperature. Proteins not bound to the resin were separated by centrifugation at $700 \mathrm{~g}$ for $5 \mathrm{~min}$ on a swingout rotor. The resin was washed twice with $50 \mathrm{~mL}$ of buffer A, transferred to a $1.5 \mathrm{~cm}$ diameter Econo-Column chromatography column (Bio-Rad Laboratories) and washed with another $50 \mathrm{~mL}$ of buffer A and $50 \mathrm{~mL}$ of buffer A supplemented with $10 \mathrm{mM}$ imidazole. To separate $M A \beta$ from the resin-bound $Z_{A \beta 3}$, the drained resin was resuspended in $40 \mathrm{~mL}$ of buffer SL (buffer A supplemented with $6 \mathrm{M}$ guanidine hydrochloride ( $\mathrm{GdmCl}), \mathrm{pH}$ 7.2) and incubated for $30 \mathrm{~min}$ at room temperature. The denatured MA $\beta$ peptide was recovered in the filtrate upon filtration of the resin slurry through the Econo-Column chromatography column.

Native MA $\beta$ was obtained by SEC of the denatured MA $\beta$ on a Superdex 75 HR 10/300 column (GE Healthcare) equilibrated with $20 \mathrm{mM}$ sodium phosphate, $50 \mathrm{mM}$ sodium chloride, $\mathrm{pH7}$.2. If protein concentration or storage was desired, the $\mathrm{pH}$ of the SEC eluate was adjusted to basic $\mathrm{pH}(\sim 10.5)$ directly after elution, as basic $\mathrm{pH}$ preserves the monomeric state of $\mathrm{A} \beta$ and is thus advantageous for stock solutions $[38,54]$. Concentration of the basic protein solutions was achieved using Vivaspin concentration columns (Sartorius). The identity of the peptides was verified by mass spectrometry $(\mathrm{MA} \beta(1-40)$, theoretical mass: 4458.2 Da, experimental mass: 4458.1 Da; MA $\beta(1-42)$, theoretical mass: 4642.3 Da, experimental mass: $4642.3 \mathrm{Da})$. Peptide concentrations in solution were measured by UV spectroscopy $\left(\varepsilon_{280}-\varepsilon_{300}=1424 \mathrm{M}^{-1}\right.$ $\left.\mathrm{cm}^{-1}\right)$.

For analysis of the coexpressed $M A \beta: Z_{A \beta 3}$ complex, the entire complex (i.e. without separation of the complex's constituents under denaturing conditions) was eluted from the IMAC column with buffer A supplemented with $150 \mathrm{mM}$ imidazole, and subjected to SDS-PAGE (Figure 2, lane 4). NMR measurements on the complex (Figure 3) were carried out after an additional SEC step using a Superdex 75 HR 10/300 column equilibrated with 20 mM potassium phosphate, $\mathrm{pH}$ 7.2.

\section{$\boldsymbol{A} \beta$ peptides}

$\mathrm{A} \beta$ was obtained from a commercial source (rpeptide). $\mathrm{A} \beta(1-40)$ was purchased either $\mathrm{NaOH}$ pre-treated or HFIP pre-treated, dissolved in $30 \mathrm{mM}$ ammonium hydroxide to a concentration of $0.5 \mathrm{mM}$, and diluted into the final experiment buffer. $A \beta(1-42)$ was purchased HFIP pre-treated. To ensure disaggregation of $A \beta(1-42)$, the peptide was dissolved in $6 \mathrm{M} \mathrm{GdmCl}$ (buffer SL) and subjected to SEC, using the same conditions as employed in the final step of the MA $\beta$ purification protocol.

\section{Analytical size exclusion chromatography}

Peptides at a concentration of $40-100 \mu \mathrm{M}$ were analyzed on a Superdex 75 HR 10/300 column equilibrated in 20 $\mathrm{mM}$ sodium phosphate, $50 \mathrm{mM}$ sodium chloride, $\mathrm{pH}$ 7.2. Elution profiles were normalized to unity at maximum absorbance for the purpose of comparison.

\section{Circular dichroism spectroscopy}

Far-UV CD measurements were performed on a JASCO J810 spectropolarimeter using a $0.1 \mathrm{~cm}$ path length cuvette. Peptides were used at concentrations of 20-25 $\mu \mathrm{M}$ in $20 \mathrm{mM}$ phosphate, $\mathrm{pH} 7.2-7.4$. Spectra were recorded at $20^{\circ} \mathrm{C}$. Thirty scans were averaged without smoothing and corrected for the buffer spectrum.

\section{Electron microscopy}

Samples were applied to formvar/carbon coated nickel grids, stained with $2 \%(\mathrm{w} / \mathrm{v})$ uranyl acetate and viewed in a LEO 912 AB Omega transmission electron microscope.

\section{NMR spectroscopy}

NMR was measured using Varian Inova $800 \mathrm{MHz}$ and 900 $\mathrm{MHz}$ spectrometers. Samples of the $\mathrm{MA} \beta: \mathrm{Z}_{\mathrm{A} \beta 3}$ complex prepared after IMAC and SEC purification contained 160 $\mu \mathrm{M}$ complex in $20 \mathrm{mM}$ potassium phosphate, $\mathrm{pH} 7.2$, with $10 \% \mathrm{D}_{2} \mathrm{O}$. Samples of purified MA $\beta$ and commercial $\mathrm{A} \beta$ peptides contained $c a$. $60 \mu \mathrm{M}{ }^{15} \mathrm{~N}$-labeled peptides in $20 \mathrm{mM}$ sodium phosphate, $50 \mathrm{mM}$ sodium chloride, $\mathrm{pH}$ 7.2 , with $10 \% \mathrm{D}_{2} \mathrm{O}$. NMR data were processed using NMRpipe [55] and analyzed using CcpNmr Analysis [56].

\section{Thioflavin T amyloid formation assay}

Thioflavin T fluorescence was recorded in 96-well plates (Nunc) using a FLUOstar Optima reader (BMG) equipped with $440 \mathrm{~nm}$ excitation and $480 \mathrm{~nm}$ emission filters. The samples contained $100 \mathrm{ml}$ of $25 \mu \mathrm{MMA} \beta(1-42)$ or $\mathrm{A} \beta(1-$ 42 ) in $20 \mathrm{mM}$ Na-phosphate, $50 \mathrm{mM}$ sodium chloride, pH 7.2, supplemented with $10 \mu \mathrm{M}$ thioflavin T. Plates were sealed with polyolefin tape (Nunc) and incubated at $37^{\circ} \mathrm{C}$. Data points were recorded every $10 \mathrm{~min}$ with $50 \mathrm{sec}$ of orbital shaking (width $5 \mathrm{~mm}$ ) preceding each measurement.

\section{Authors' contributions}

BM carried out the major part of the DNA work and established the purification protocol. WH carried out the major part of the peptide characterization and wrote the final version of the manuscript. AS conceived of the study and 
participated in establishing the purification protocol and in circular dichroism studies. ACB and CMD participated in designing and performing electron microscopy experiments. TH participated in the design of the study, coordinated it, and participated in the NMR experiments. All authors read and approved the final manuscript.

\section{Acknowledgements}

This work was supported by the Swedish Research Council (VR), the German Academic Exchange Service, and the MIVAC Swedish Foundation for Strategic Research (SSF) Center. We thank Professor Stefan Ståhl, Caroline Gröwall, Andreas Jonsson, and Affibody AB for the provision of binding protein constructs and fruitful discussions.

\section{References}

I. Mount C, Downton C: Alzheimer disease: progress or profit? Nat Med 2006, I2(7):780-784.

2. Findeis MA: The role of amyloid $\beta$ peptide 42 in Alzheimer's disease. Pharmacol Ther 2007, I I6(2):266-286.

3. Haass C, Selkoe DJ: Soluble protein oligomers in neurodegeneration: lessons from the Alzheimer's amyloid $\beta$-peptide. Nat Rev Mol Cell Biol 2007, 8(2): I0I-I I 2

4. Bitan G, Fradinger EA, Spring SM, Teplow DB: Neurotoxic protein oligomers - what you see is not always what you get. Amyloid 2005, I 2(2):88-95.

5. Lambert MP, Barlow AK, Chromy BA, Edwards C, Freed R, Liosatos M, Morgan TE, Rozovsky I, Trommer B, Viola KL, et al.: Diffusible, nonfibrillar ligands derived from $A \beta_{I_{-42}}$ are potent central nervous system neurotoxins. Proc Natl Acad Sci USA 1998, 95(I I):6448-6453.

6. Walsh DM, Klyubin I, Fadeeva JV, Cullen WK, Anwyl R, Wolfe MS, Rowan MJ, Selkoe DJ: Naturally secreted oligomers of amyloid $\beta$ protein potently inhibit hippocampal long-term potentiation in vivo. Nature 2002, 416(6880):535-539.

7. Wolfe MS, Guenette SY: APP at a glance. J Cell Sci 2007, | 20(18):3|57-3|6|

8. Johansson AS, Berglind-Dehlin F, Karlsson G, Edwards K, Gellerfors $P$, Lannfelt L: Physiochemical characterization of the Alzheimer's disease-related peptides $A \beta I-42 A r c t i c$ and $A \beta I-$ 42wt. FEBS J 2006, 273(I2):2618-2630.

9. Nilsberth $C$, Westlind-Danielsson A, Eckman CB, Condron MM, Axelman K, Forsell C, Stenh C, Luthman J, Teplow DB, Younkin SG, et al.: The 'Arctic' APP mutation (E693G) causes Alzheimer's disease by enhanced Abeta protofibril formation. Nat Neurosci 200I, 4(9):887-893.

10. Chimon S, Shaibat MA, Jones CR, Calero DC, Aizezi B, Ishii Y: Evidence of fibril-like $\beta$-sheet structures in a neurotoxic amyloid intermediate of Alzheimer's $\beta$-amyloid. Nat Struct Mol Biol 2007, I 4( I 2): I I57-II64.

II. Lührs T, Ritter C, Adrian M, Riek-Loher D, Bohrmann B, Döbeli H, Schubert $D$, Riek R: 3D structure of Alzheimer's amyloid- $\beta$ (I42) fibrils. Proc Natl Acad Sci USA 2005, I 02(48): I7342- 17347.

12. Petkova AT, Yau WM, Tycko R: Experimental constraints on quaternary structure in Alzheimer's $\beta$-amyloid fibrils. Biochemistry 2006, 45(2):498-5I2.

13. Sørensen HP, Mortensen KK: Advanced genetic strategies for recombinant protein expression in Escherichia coli. J Biotechnol 2005, II 5(2): II3-128.

14. Sharpe S, Yau WM, Tycko R: Expression and purification of a recombinant peptide from the Alzheimer's $\beta$-amyloid protein for solid-state NMR. Protein Expr Purif 2005, 42(I):200-2I0.

15. Lopes DH, Colin C, Degaki TL, de Sousa AC, Vieira MN, Sebollela A, Martinez AM, Bloch C Jr, Ferreira ST, Sogayar MC: Amyloidogenicity and cytotoxicity of recombinant mature human islet amyloid polypeptide (rhIAPP). J Biol Chem 2004, 279(4I):42803-428I0.

16. Mazor Y, Gilead S, Benhar I, Gazit E: Identification and characterization of a novel molecular-recognition and self-assembly domain within the islet amyloid polypeptide. J Mol Biol 2002, 322(5): $1013-1024$.

17. Döbeli H, Draeger N, Huber G, Jakob P, Schmidt D, Seilheimer B, Stuber $D$, Wipf $B$, Zulauf M: A biotechnological method provides access to aggregation competent monomeric Alzheimer's I-42 residue amyloid peptide. Biotechnology 1995, 13(9):988-993.

18. Hortschansky P, Schroeckh V, Christopeit T, Zandomeneghi G, Fändrich M: The aggregation kinetics of Alzheimer's $\beta$-amyloid peptide is controlled by stochastic nucleation. Protein Sci 2005, I4(7): 1753-1759.

19. Lee EK, Hwang JH, Shin DY, Kim DI, Yoo YJ: Production of recombinant amyloid- $\beta$ peptide 42 as an ubiquitin extension. Protein Expr Purif 2005, 40(I): 183-189.

20. Shahnawaz M, Thapa A, Park IS: Stable activity of a deubiquitylating enzyme (Usp2-cc) in the presence of high concentrations of urea and its application to purify aggregation-prone peptides. Biochem Biophys Res Commun 2007, 359(3):80I-805.

21. Thapa A, Shahnawaz M, Karki P, Raj Dahal G, Golam Sharoar M, Yub Shin S, Sup Lee J, Cho B, Park IS: Purification of inclusion bodyforming peptides and proteins in soluble form by fusion to Escherichia coli thermostable proteins. Biotechniques 2008, 44(6):787-796.

22. Nagata-Uchiyama M, Yaguchi M, Hirano Y, Ueda T: Expression and purification of uniformly ${ }^{15} \mathrm{~N}$-labeled amyloid $\beta$ peptide $\mathrm{I}-40$ in Escherichia coli. Protein Pept Lett 2007, 14(8):788-792.

23. Tolia NH, Joshua-Tor L: Strategies for protein coexpression in Escherichia coli. Nat Methods 2006, 3(1):55-64.

24. Henricksen LA, Umbricht CB, Wold MS: Recombinant replication protein A: expression, complex formation, and functional characterization. J Biol Chem 1994, 269( I5): I I I 2I-I I I 32.

25. Li C, Schwabe JW, Banayo E, Evans RM: Coexpression of nuclear receptor partners increases their solubility and biological activities. Proc Natl Acad Sci USA 1997, 94(6):2278-2283.

26. Romier C, Ben Jelloul M, Albeck S, Buchwald G, Busso D, Celie PH, Christodoulou E, De Marco V, van Gerwen S, Knipscheer P, et al: Co-expression of protein complexes in prokaryotic and eukaryotic hosts: experimental procedures, database tracking and case studies. Acta Crystallogr D 2006, 62 ( I 0): I 232-I 242.

27. Stebbins CE, Kaelin WG Jr, Pavletich NP: Structure of the VHLElonginC-ElonginB complex: implications for VHL tumor suppressor function. Science 1999, 284(54I3):455-46I.

28. Schlieker C, Bukau B, Mogk A: Prevention and reversion of protein aggregation by molecular chaperones in the $E$. coli cytosol: implications for their applicability in biotechnology. J Biotechnol 2002, 96(I):|3-2|.

29. Thomas JG, Ayling A, Baneyx F: Molecular chaperones, folding catalysts, and the recovery of active recombinant proteins from E. coli. Appl Biochem Biotechnol 1997, 66(3):197-238.

30. Grönwall C, Jonsson A, Lindstrom S, Gunneriusson E, Ståhl S, Herne $\mathrm{N}$ : Selection and characterization of Affibody ligands binding to Alzheimer amyloid $\beta$ peptides. J Biotechnol 2007, I 28(I):162-183.

31. Nygren PÅ: Alternative binding proteins: Affibody binding proteins developed from a small three-helix bundle scaffold. FEBS J 2008, 275(II):2668-2676.

32. Nord K, Gunneriusson E, Ringdahl J, Ståhl S, Uhlén M, Nygren PÅ Binding proteins selected from combinatorial libraries of an a-helical bacterial receptor domain. Nat Biotechnol 1997 , I 5(8):772-777.

33. Hoyer W, Grönwall C, Jonsson A, Ståhl S, Härd T: Stabilization of a $\beta$-hairpin in monomeric Alzheimer's amyloid- $\beta$ peptide inhibits amyloid formation. Proc Natl Acad Sci USA 2008, 105(13):5099-5104.

34. Gardberg AS, Dice LT, Ou S, Rich RL, Helmbrecht E, Ko J, Wetzel R, Myszka DG, Patterson PH, Dealwis C: Molecular basis for passive immunotherapy of Alzheimer's disease. Proc Natl Acad Sci USA 2007, I 04(40): I5659-I5664.

35. Hou L, Shao H, Zhang Y, Li H, Menon NK, Neuhaus EB, Brewer JM, Byeon IJ, Ray DG, Vitek MP, et al.: Solution NMR studies of the $A \beta(I-40)$ and $A \beta(I-42)$ peptides establish that the Met35 oxidation state affects the mechanism of amyloid formation. J Am Chem Soc 2004, I 26(7): 1992-2005.

36. Hepler RW, Grimm KM, Nahas DD, Breese R, Dodson EC, Acton P, Keller PM, Yeager M, Wang H, Shughrue P, et al:: Solution state characterization of amyloid $\beta$-derived diffusible ligands. Biochemistry 2006, 45(5 I): 15157-15167.

37. Walsh DM, Lomakin A, Benedek GB, Condron MM, Teplow DB: Amyloid beta-protein fibrillogenesis. Detection of a protofibrillar intermediate. J Biol Chem 1997, 272(35):22364-22372. 
38. Fezoui $Y$, Hartley DM, Harper JD, Khurana R, Walsh DM, Condron MM, Selkoe DJ, Lansbury PT Jr, Fink AL, Teplow DB: An improved method of preparing the amyloid $\beta$-protein for fibrillogenesis and neurotoxicity experiments. Amyloid 2000, 7(3): 166-I78.

39. Terzi E, Holzemann G, Seelig J: Self-association of $\beta$-amyloid peptide $(\mathrm{I}-40)$ in solution and binding to lipid membranes. J Mol Biol 1995, 252(5):633-642.

40. LeVine $H$ 3rd: Quantification of $\beta$-sheet amyloid fibril structures with thioflavin T. Methods Enzymol 1999, 309:274-284.

4I. Wang $\mathrm{H}$, Chong $\mathrm{S}$ : Visualization of coupled protein folding and binding in bacteria and purification of the heterodimeric complex. Proc Natl Acad Sci USA 2003, I 00(2):478-483.

42. Hoyer W, Härd T: Interaction of Alzheimer's A $\beta$ peptide with an engineered binding protein - thermodynamics and kinetics of coupled folding-binding. J Mol Biol 2008, 378(2):398-4I I.

43. Binz HK, Amstutz P, Plückthun A: Engineering novel binding proteins from nonimmunoglobulin domains. Nat Biotechnol 2005, 23(10): I257- 1268.

44. Wiesehan K, Funke SA, Fries M, Willbold D: Purification of recombinantly expressed and cytotoxic human amyloid-beta peptide I-42. J Chromatogr B 2007, 856(I-2):229-233.

45. Gorman PM, Chakrabartty A: Alzheimer beta-amyloid peptides: structures of amyloid fibrils and alternate aggregation products. Biopolymers 200I, 60(5):38I-394.

46. Stine WB Jr, Dahlgren KN, Krafft GA, LaDu MJ: In vitro characterization of conditions for amyloid-beta peptide oligomerization and fibrillogenesis. J Biol Chem 2003, 278(I3): I I6 I 2-I I622.

47. Carrotta R, Di Carlo M, Manno M, Montana G, Picone P, Romancino $D$, San Biagio PL: Toxicity of recombinant $\beta$-amyloid prefibrillar oligomers on the morphogenesis of the sea urchin Paracentrotus lividus. FASEB / 2006, 20(II): 1916-1917.

48. Lesley SA: High-throughput proteomics: protein expression and purification in the postgenomic world. Protein Expr Purif 200I, 22(2):159-164.

49. Thiel MA, Coster DJ, Mavrangelos C, Zola H, Williams KA: An economical 20 litre bench-top fermenter. Protein Expr Purif 2002, 26(I): $14-18$.

50. Meinhardt J, Tartaglia GG, Pawar A, Christopeit T, Hortschansky P, Schroeckh V, Dobson CM, Vendruscolo M, Fändrich M: Similarities in the thermodynamics and kinetics of aggregation of disease-related $A \beta(\mathrm{I}-40)$ peptides. Protein Sci 2007, 16(6): 12|4-1222.

5I. Peim A, Hortschansky P, Christopeit T, Schroeckh V, Richter W, Fändrich M: Mutagenic exploration of the cross-seeding and fibrillation propensity of Alzheimer's $\beta$-amyloid peptide variants. Protein Sci 2006, I5(7): 180I-I805.

52. Hou L, Zagorski MG: NMR reveals anomalous copper(II) binding to the amyloid $\mathbf{A} \beta$ peptide of Alzheimer's disease. J $\mathrm{Am}$ Chem Soc 2006, I 28(29):9260-926I.

53. Grant MA, Lazo ND, Lomakin A, Condron MM, Arai H, Yamin G, Rigby AC, Teplow DB: Familial Alzheimer's disease mutations alter the stability of the amyloid $\beta$-protein monomer folding nucleus. Proc Natl Acad Sci USA 2007, 104(42): 16522-16527.

54. Huang TH, Yang DS, Plaskos NP, Go S, Yip CM, Fraser PE, Chakrabartty A: Structural studies of soluble oligomers of the Alzheimer $\beta$-amyloid peptide. J Mol Biol 2000, 297(I):73-87.

55. Delaglio F, Grzesiek S, Vuister GW, Zhu G, Pfeifer J, Bax A: NMRpipe: A multidimensional spectral processing system based on UNIX pipes. J Biomol NMR I995, 6(3):277-293.

56. Vranken WF, Boucher W, Stevens TJ, Fogh RH, Pajon A, Llinas M, Ulrich EL, Markley JL, lonides J, Laue ED: The CCPN data mode for NMR spectroscopy: development of a software pipeline. Proteins 2005, 59(4):687-696.
Publish with Bio Med Central and every scientist can read your work free of charge

"BioMed Central will be the most significant development for disseminating the results of biomedical research in our lifetime. "

Sir Paul Nurse, Cancer Research UK

Your research papers will be:

- available free of charge to the entire biomedical community

- peer reviewed and published immediately upon acceptance

- cited in PubMed and archived on PubMed Central

- yours - you keep the copyright

Submit your manuscript here:

http://www.biomedcentral.com/info/publishing_adv.asp
BioMedcentral 